\section{Checking out creationism}

Tony Thulborn

Dictionary of Science \& Creationism. By Ronald L. Ecker. Prometheus: 1990. Pp. 263. $\$ 32.95, £ 24.50$.

THE war of words between creationism and science rumbles on incessantly, plunging the general public into everdeepening confusion about the meaning of the word 'science'. Optimists believe that the creationist crusade has suffered some resounding defeats - notably in the US state legislatures of Arkansas (1982) and Louisiana (1987) - but, in reality, these were hollow victories for science. The plain truth is that a handful of Biblethumping extremists has corrupted what little the public knew of science in the first place. Today, nine out of ten adult Americans are "scientifically illiterate"; half of them reject outright the very thought of human evolution; and in some US states almost half of biology teachers favour the introduction of creationism in high schools.

Over the past 10 years increasing numbers of scientists have elected to stand and fight, principally by showering remedial publications upon the mountainous literature of creationism. Anyone now contemplating the overburdened bookshelves of science and pseudoscience will probably be grateful to Ronald Ecker for providing a convenient guidebook to the whole sorry mess.

Despite the title "Dictionary", Ecker's book contains only 72 text-entries. These, however, are fairly substantial essays, many of them entertaining as well as informative. In narrating the historical, legal and social aspects of creationism, Ecker - a librarian by profession - is at his best. His style is perfectly matched to the material: commendably sane and sober, but strewn with creationist gems of mindcurdling inanity. Readers may be unable to suppress their laughter on encountering the "glory meter" - an instrument for detecting whether or not you've been born again - while home gardeners will surely be diverted by creationism's official pronouncement that plants are not living organisms. Forthright souls, heading straight for the heart of the matter (under "Satan"), will learn that UFOs really do exist... on the unimpeachable authority of Reader's Digest. Such are the towering achievements of creation 'science'.

As a dictionary of creationism, Ecker's work is difficult to fault. Its few and minor flaws are more than offset by an excellent bibliography (more than 500 titles) and an exhaustive index. My only grumble is that Ecker concentrates almost exclusively on US creationism and its literature. His readers will never suspect that the world's second-largest creation ministry is based in Australia, or that creationist outposts exist as far afield as Brazil, South Africa and New Zealand.

As a dictionary of science, Ecker's book is sound but unremarkable. It draws heavily on the second-hand generalizations of textbooks and review articles, reproducing both their strengths and, alas, their weaknesses. Thus, I regret to report, Ecker's compendium failed my preliminary test for any dictionary of science - which is to examine the entry for "homology". My standard for comparison is the Penguin Dictionary of Biology, which struggles with this nebulous concept for about 200 words, eventually confessing that it is "a matter of opinion". Ecker defines homology (under "anatomy") as anatomical similarity "due to common evolutionary descent". Then, under "evolution", he discloses that homologous structures are "prime evidence of shared evolutionary origin". Circularities like this are the breadand-butter of creationism.

It is equally disappointing to read that "the evidence for biological evolution begins with the fossil record". This seemingly indestructible myth is the mainstay of creationism, which thrives on the existence of gaps in the fossil record. The primary evidence for evolution is, of course, all around us in living organisms, as Charles Darwin explained in 1859.
Ecker should not be condemned for innocently reproducing the verbal blunders of science. Blame should rightly go to those scientists whose carelessness with the English language has provided creationism with so much of its ammunition. The biologist who first described a mutation as "an error" probably received a Nobel prize, instead of a well-earned reprimand. Ecker repeats the description "an error", thereby inviting more sophistry from creationism: namely, an accumulation of errors cannot possibly result in evolutionary progress.

Given the shortcomings of scientific

Creation of the universal argument?

literature, Ecker does a creditable job. But such honest craftsmanship will not make the slightest dent in the carapace of creationism, as Martin Gardner is forced to admit in his foreword to the book. Nor, despite Gardner's hope, will it affect the thinking of politicians: they will continue to deplore the practices of Islamic fundamentalism, while encouraging the growth of Christian fundamentalism in their own back yards.

Complacent reviewers may well describe Ecker's dictionary as a valuable contribution, another handy tool for shovelling back the mire of ignorance. Seasoned campaigners, who engage creationists in classrooms and public debates, will disagree. They know, from painful experience, that a catalogue of facts and fallacies has no perceptible impact on public opinion. If science is to survive the smear-campaign of creationism, it must be made intelligible to the whole of society. And that awesome task is the responsibility of scientists - not of chivalrous bystanders like Ronald Ecker.

Tony Thulborn is in the Department of Zoology, University of Queensland, St Lucia, Brisbane. Queensland 4072, Australia. 